Thorax (1960), 15, 212.

\title{
A SYNDROME RESEMBLING FARMER'S LUNG IN WORKERS INHALING SPORES OF ASPERGILLUS AND PENICILLIA MOULDS
}

\author{
BY \\ MILOŠ HOŘEJŠÍ, JOSEF ŠACH, ALENA TOMŠÍKOVÁ, AND ANTONÍN MECL \\ With TeChNical Assistance from \\ DANA BLAHNÍKOVÁ, MILADA TƯMOVÁ AND ANEŽKA VALIŠOVÁ \\ From the Clinic for Internal Medicine and Bacteriological Institute, Plzeň, Czechoslovakia
}

(RECEIVED FOR PUBLICATION JANUARY 20, 1960)

The effects of moulds on humans, and especially on the respiratory tract, have been of interest to many investigators (Virchow, 1856; Dévé, 1938; Riddell, 1956; Wegmann, 1956; Clayton, 1958; Staib and Ata, 1958). Some moulds are pathogenic, but there are others, such as aspergilli, which can produce lung disease only in certain circumstances. There is still no agreement about their relationship to macro-organisms, but roughly four types of activity are recognized (Dévé, 1938; Hinson, Moon, and Plummer, 1952; Frankland and Hamilton, 1958), namely:

(1) Saprophytic.-Settling without any obvious reaction on the part of the host.

(2) Allergic.-Most frequently manifested as bronchial asthma (Fawcitt, 1938; Törnell, 1946; Hinson et al., 1952; Fuller, 1953; Studdert, 1953; Frankland and Hamilton, 1958).

(3) Production of proper fungous lung diseases.

(4) Doubtful fungal aetiology : farmer's lung.

We have investigated a group of subjects working for many years in environments containing great quantities of spores of aspergillus and penicillia, without any admixture of dust or other pathogenic organisms. From this investigation we tried to answer the following questions of general interest :

(1) Does massive inhalation of moulds produce a fungous disease of the lungs, bronchial asthma, or farmer's lung syndrome?

(2) Does inhalation of moulds influence the functional efficiency of the lungs ?

(3) Does inhalation of moulds produce specific antibody formation in the blood, positive culture findings in the respiratory tract, and skin hypersensitivity to them ?
(4) Do the mycological and serological findings bear any relation to the clinical symptoms and are they of any diagnostic value?

(5) Are the objective findings and subjective $\mathbb{Q}$ symptoms caused by aspergilli or penicillia?

\section{MATERIALS AND METHODS}

In a factory where molasses was fermented aspergilli for the industrial production of citric acif 61 men were examined who had worked or who st worked in an atmosphere containing great quantities spores of aspergilli and penicillia. The fermentation $\mathbb{D}$ is carried out in large open pans, and when the process is finished the thick layer of : spergillus culture is $\overrightarrow{0}$ removed by the workers and at this time spore dust is produced.

Subjects were divided into two groups:

Group I comprised 38 men of average age 32, who had been working in this plant for from three months to 18 응 years. Every third day they worked in dense clouds of $\underset{x}{x}$ mould spores, protected by cottonwool filters applied $:$ to the nose and mouth. For the remaining two days they did other general work, and from time to time they were obliged to sterilize the cultivation vessels with $\frac{0}{3}$ formalin fumes.

Group II comprised 23 workers of average age 51.6 윽 years, who had discontinued this work because of various $D$ symptoms. Nine of them, after an average exposure of ․ㅡㄹ 7.4 years to the mould dust, do general work in the neighbouring plant, where the moulds can only penetrate $O$ occasionally on the current of air from the main plant. $N$ The remaining 14 men left the work after an average $N$ exposure of 9.2 years, mainly because of increasing $\mathrm{\omega}$ dyspnoea.

The control group consisted of 25 in-patients of our 6 ward suffering from diseases other than lung diseases $\mathbb{D}$ (Group A), another 25 patients with chronic bronchitis $\stackrel{?}{?}$ (Group B), and 54 healthy individuals (Group C). In all 7 of them the bacteriological and clinical examination was made in the same way as in the tested groups. 
All the tested subjects had their history taken, and were physically examined. Fluoroscopy was then carried out, chest radiographs taken, and the forced expiratory capacity measured and evaluated by the index of vital capacity (I.V.C.) (Kadlec and Vyskočil, 1954), the normal value being above 1 and the pathological value below 1 . In addition, a blood cell count was made and the red cell sedimentation rate read for one and two hours. Sputum and laryngeal swabs were examined microscopically and cultivated on the usual bacteriological (including media for $M$. tuberculosis) and mycological media (Sabouraud, Czapek-Dox, and Littman's ox gall agar). In all patients we used the collodion agglutination method of Cavelti and Wagner (Cavelti, 1947; Wagner and Rejholec, 1952; Wagner, 1954; Seeliger, 1958) whereby antibodies against Aspergillus fumigatus, A. niger, and six species of penicillia found in the sputum or laryngeal swabs were sought. The collodion particles were mixed with collodion antigen $1: 20$. The mixture was added to the diluted serum of the patients to be examined, and two hours later the mixture was centrifuged and after shaking read macroscopically. Flocculation was read as a positive reaction. (The detailed method will be published in Zeitschrift für Immunitätsforschung.) Skin sensitivity to these moulds was examined by the scratch test and by intradermal application (Mitze, 1953; Dyson and Evans, 1955; Kaplan, 1955; Hajos, 1956; Sternberger, Feinberg, Feinberg, Clarke, Benaim, and Warren, 1956; Epstein, Prince, and Morrow, 1957; Johnson and Hampton, 1957; Jillson, 1957). The antigen for skin and serological reactions was prepared from the filtrate of moulds by three methods: (1) freezing and defreezing, (2) warming up to $100^{\circ} \mathrm{C}$., and (3) on ultrasonic destructive technique. The skin reactions were read after 30 minutes and 24 , 48 , and 96 hours.

The subjects were examined in our ward at least 24 hours after the last exposure to moulds. In addition 38 workers were tested in the plant while working with the moulds. The presence of spores in the air was examined by exposing mycological media for five to 60 seconds directly in the plant.

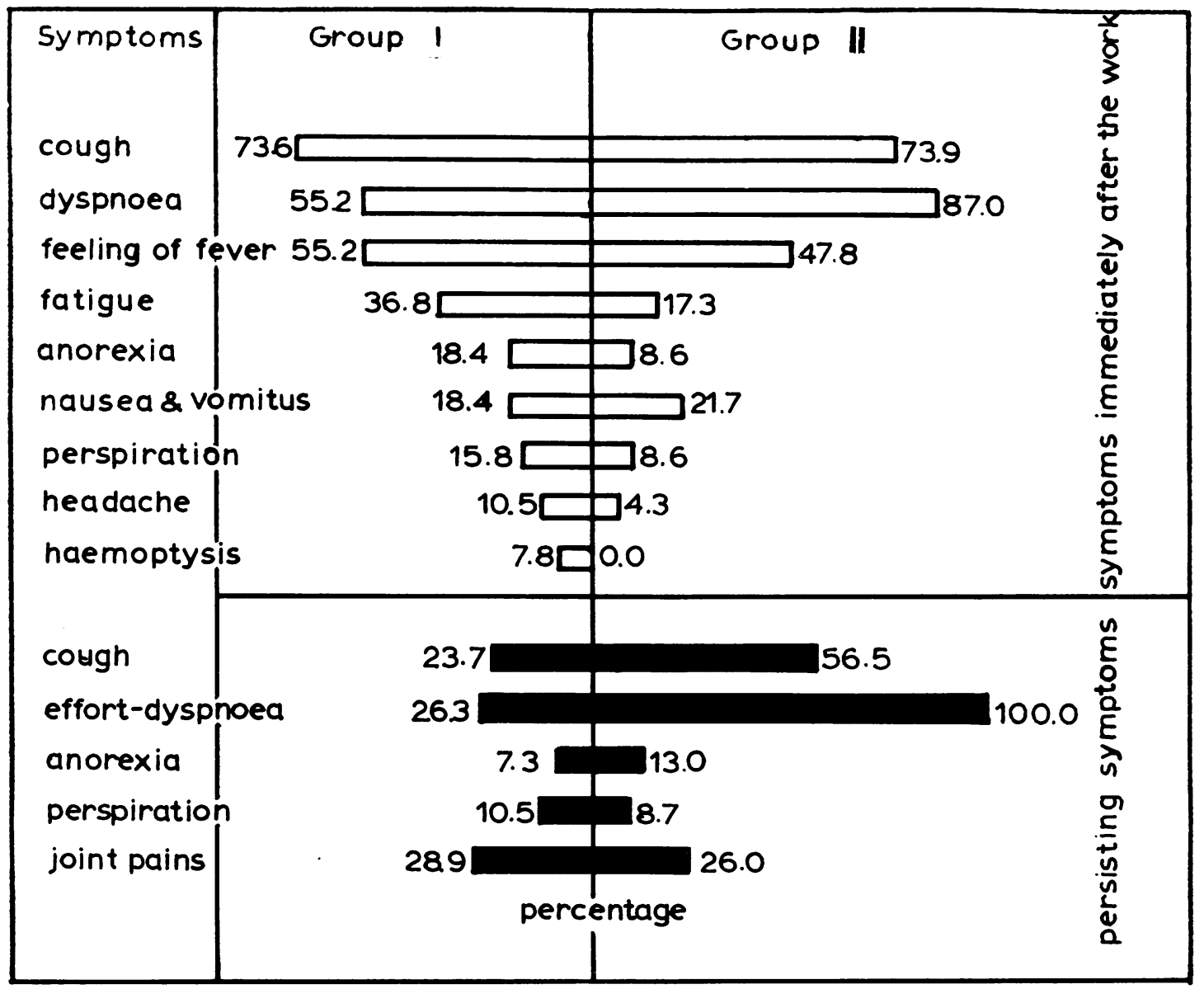

FIG. 1.-Comparison of persistent symptoms and symptoms immediately after work. 


\section{RESULTS}

From 38 subjects of the first group, 93.5\% reported symptoms when examined immediately after finishing the work with the moulds. These symptoms are summarized in Fig. 1.

Cough and dyspnoea and tightness of the chest were the principal symptoms in $73.6 \%$ and $55.2 \%$ respectively. Wheezing was heard even by the workers themselves, and some expectorated viscous greyish-black sputum. When the cough stopped, so did the dyspnoea, and after six to eight hours all symptoms had disappeared. In addition, 55.2\% felt feverish, $36.8 \%$ were fatigued, and $18.4 \%$ had nausea and vomiting.

Complaints of those in Group II immediately after working with the moulds were similar, and dyspnoea in particular was more frequent $(87 \%)$. All the symptoms described were absent in the same subjects on the days when other work was performed. On the other hand, the complaints were more pronounced after a longer interval between work (such as after holidays), and whenever " green spores " (contamination of Aspergillus fumigatus by penicillia) were inhaled. After the inhalation of
" black spores" (Aspergillus niger) the complaints $\overrightarrow{\overline{\mathrm{F}}}$ were fewer.

Chest radiographs did not show any changes? before and after the onset of symptoms (Table 1). 흥 The forced expiratory capacity was reduced (average $\frac{\widehat{\sigma}}{\widetilde{\sigma}}$

TABLE I

PATHOLOGICAL CHANGES IN GROUP I IMMEDIATELY AFTER WORK

Auscultatory signs of bronchitis

Radiological

Transient lung infiltration"

Pathological I.V.C.

Raised E.S.R.

Eosinophilia

I.V.C. lower by 0.7) compared with the results obtained before working with the moulds.

Persistent symptoms (Fig. 1) had a different pattern from symptoms arising immediately after $(\Omega)$ work. In Group I there were few complaints joint pains in $28.9 \%$ and effort dyspnoea in $26.3 \%$. A.ll the subjects in Group II had effort dyspnoea and $56.5 \%$ had cough.

The results of examination of the same subjects $\overrightarrow{0}$ (Group 1 and Group II) are given in Table 11.8

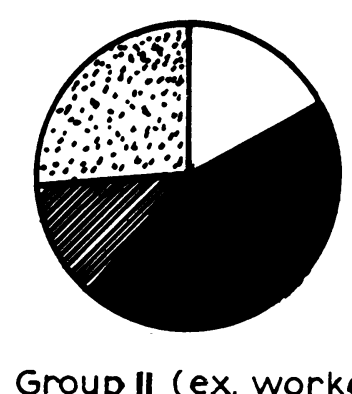

Group || (ex. workers)

\section{Group I (workers)}

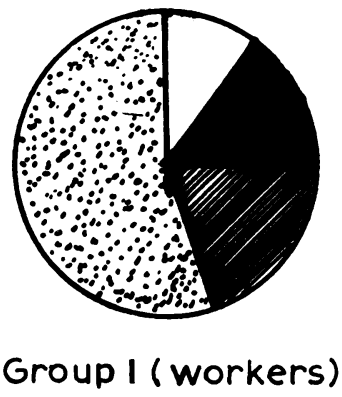

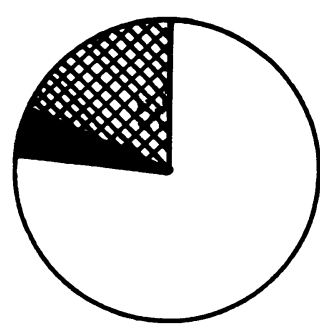

A

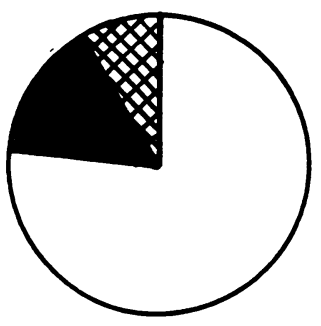

B

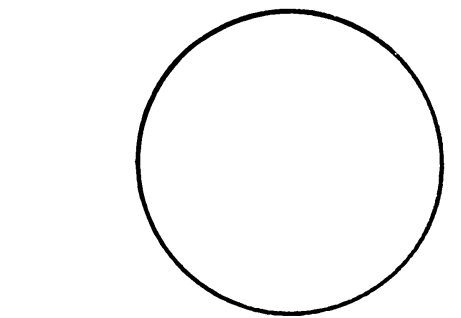

C

penicillia+ other sorts aspergilli of moulds

FIG. 2.-Proportion of moulds in respiratory tracts in Groups I and II and controls. 
TABLE II

PATHOLOGICAL CHANGES IN GROUPS I AND II DURING EXAMINATION IN THE WARD

\begin{tabular}{|c|c|c|c|c|c|}
\hline \multicolumn{4}{|c|}{ Abnormal Signs } & Group I $(\%)$ & Group II (\%) \\
\hline $\begin{array}{l}\text { Auscultatory signs o } \\
\text { Radiological , } \\
\text { Transient lung infilt } \\
\text { Radiological signs o } \\
\text { Pathological I. V.C. } \\
\text { Raised E.S.R. . } \\
\text { Eosinophilia } \\
\text { Epicermophytia } \\
\text { Mean I.V.C. . } \\
\text {. }\end{array}$ & $\begin{array}{l}\text { ron } \\
\text { ion } \\
\text { lber } \\
\ldots \\
\cdots \\
\ldots \\
\ldots \\
\cdots\end{array}$ & $\begin{array}{l}\text { itis } \\
\ldots \\
\text { losis } \\
\ldots \\
\cdots \\
\ldots \\
\ldots\end{array}$ & $\begin{array}{l}\cdots \\
\cdots \\
\cdots \\
\cdots \\
\cdots \\
\cdots \\
\cdots\end{array}$ & $\begin{array}{l}39 \cdot 9 \\
63 \cdot 0 \\
0 \\
0 \\
0 \\
13 \cdot 1 \\
13 \cdot 1 \\
39 \cdot 4 \\
3 \cdot 1\end{array}$ & $\begin{array}{l}71 \\
85 \cdot 7 \\
0 \\
13 \\
25 \\
11 \cdot 1 \\
20 \\
18 \cdot 1 \\
0 \cdot 62\end{array}$ \\
\hline
\end{tabular}

Chronic bronchitis was found in $39.9 \%$ of Group I and in $71 \%$ of Group II. The radiographs showed augmented interstitial and peribronchial tissue patterns in $63 \%$ of the first and in $85.7 \%$ of the second group. There was no specific granulation or any other radiological manifestation of a fungous lung disease. The lung function, estimated by the forced expiratory capacity, was always normal in Group I, and essentially impaired in $25 \%$ of Group II. The blood sedimentation rate was slightly raised in $13.1 \%$ of Group I and in $11.1 \%$ of Group II. Eosinophilia over 5\% was found in $13.1 \%$ and $20 \%$ respectively. No other pathological changes in the blood were found.

The findings of moulds in the respiratory tract of the investigated groups and the controls are summarized in Fig. 2. There are striking differences in this respect between Groups I and II and the controls: completely negative in Group C, 76\% negative in Groups $A$ and $B$, and no aspergilli in any of the controls. Further, there is a marked difference between the occurrence of aspergilli and penicillia in Groups I and II.

From the species of aspergilli, Aspergillus niger van Tieghen, $A$. fumigatus Fresenius, and $A$. flavus Ling were found. From the species of penicillia Penicillium simplicissimum Thom, $P$. herquei, $P$. rubrum Stoll, $P$. caseicolum, $P$. Miczinski-Zaleski, and $P$. italicum occurred in different combinations. They were identified according to the methods given by Thom and Raper (1945), Lewis and Hopper (1948), and Raper and Thom (1949). The yeast-like fungi were present in $39.4 \%$ of Group I and in $17.8 \%$ of Group II. The common bacteriological flora of the respiratory tract were not changed. Cultures of $M$. tuberculosis were negative in all cases.

The skin sensitivity tests to the moulds mentioned above were more frequently positive in the second group of workers. In all positive tests an allergic skin reaction was immediate. The detailed results are given in Table III.

Specific antibodies against $A$. fumigatus, $A$. niger, and six species of penicillia in Groups I and II
TABLE III

SKIN HYPERSENSITIVITY TESTS IN BOTH GROUPS

\begin{tabular}{c|c|c|c}
\hline \multirow{3}{*}{ Group } & \multicolumn{3}{|c}{ Antigens } \\
\cline { 2 - 4 } & $\begin{array}{c}\text { Asper \&illus } \\
\text { niger (\%) }\end{array}$ & $\begin{array}{c}\text { Aspergillus } \\
\text { fumigatus }(\%)\end{array}$ & $\begin{array}{c}\text { Penicillia } \\
(\%)\end{array}$ \\
\hline I & $20 \cdot 6$ & $6 \cdot 8$ & $17 \cdot 2$ \\
II & $30 \cdot 0$ & $15 \cdot 0$ & $25 \cdot 0$ \\
\hline
\end{tabular}

TABLE IV

ANTIBODIES TO MOULDS IN GROUPS I AND II AND IN CONTROLS

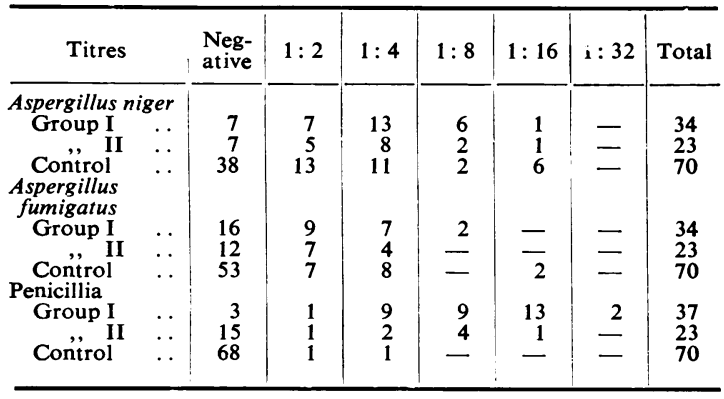

and in 70 individuals of the control group are given in Table IV. The finding of antibodies against aspergilli is similar in Groups I and II, most of the positive findings being up to a titre of 1 in 4 . An interesting finding is that of antibodies against penicillia; they were found in a greater number and in higher titres in Group I, whereas in Group II they were found in smaller numbers, and in the controls they were negative in $97.1 \%$.

\section{Discussion}

Throughout our examination of 61 men employed in a plant where great masses of spores of aspergilli and penicillia whirl in the air, we were not able to find any person suffering from a specific fungous disease of the lungs. This is in agreement with usual experience that the pulmonary aspergilloses and penicillioses are rare diseases (Wegmann, 1956; Frágner, 1958). Some intrinsic factors seem necessary in their development, in addition to extrinsic factors, such as a primary lung disease which facilitates the settling of moulds and their further pathogenic activity in the organism (Staib and Ata, 1958).

The continuous inhalation of spores of moulds results, however, in their settling down and growing on the mucous membrane of the respiratory tract (Riddell, 1958; Staib and $A$ ta, 1958). In confirmation of this hypothesis there were repeatedly positive cultures from the bronchi in $90 \%$ of workers 
examined, and positive cultures of the same species of moulds in $87 \%$ of the subjects of Group II (see Fig. 2) who discontinued working with these moulds months or years before.

In our series, $55.2 \%$ and $87 \%$ in Groups I and II respectively of workers employed or previously employed in the mould dust suffered from acute attacks of dyspnoea, very similar to those described previously by investigators such as Fawcitt (1938), Törnell (1946), Fuller (1953), Studdert (1953), as the first stage of the farmer's lung syndrome. There is a definite relation between the symptoms and the period of work with the moulds, shown by the positive cultures from the respiratory tract, specific antibodies against the moulds in the blood of workers, and positive skin sensitivity tests. The literature concerning the original farmer's lung syndrome supports this opinion, and there also the same associations have been found.

There is, however, a difference in the objective clinical picture between our patients and those with the farmer's lung syndrome. Since we were not able to find any infiltration of lung, there are presumably some other factors in farmer's lung, such as organic dust or a constitutional factor (Studdert, 1953; Essellier and Jeanneret, 1956). Our dust consisted of pure cultures of moulds as opposed to hay and straw dust in farmer's lung, and this substantial difference may account for the different clinical picture.

On the other hand, there was a high percentage of chronic bronchitis in the workers examined. In the first group, comprising subjects of average age 32 years, $39.9 \%$ suffered from this condition. This is significantly more than the incidence of chronic bronchitis in the general population of Czechoslovakia. According to the extensive investigations of Mecl and Vyskočil, the incidence of this disease averages from 8 to $12.6 \%$ of women and men respectively. In the second group of older workers the incidence of chronic bronchitis was as high as $70 \%$. Thus it seems very likely that the massive inhalation of pure moulds does not cause any damage to the lung tissue, but the damage is to the mucous membrane of the bronchial tree. We suppose that it starts with a spasm of the bronchi in response to the invasion of moulds. The repeated attacks of hyperaemia, hypersecretion, and spasm of the bronchi are consequently followed by damage to the epithelium of the mucous membrane. Thus the seeding of moulds, their growing and biological activity, are facilitated (Hinson et al., 1952; Riddell, 1958). The reaction of the tissue is inflammation, and in this way chronic bronchitis develops.
The emergence of specific antibodies proves $a \frac{\overrightarrow{\bar{s}}}{\vec{s}}$ more widespread activity of moulds on the macro- $-\frac{?}{0}$ organism. This is evident from the comparison with the controls, when, in spite of a positive culture $\frac{\bar{G}}{\bar{D}}$ finding, very few antibodies were recognized. $A_{\overparen{\Phi}}^{\overparen{D}}$ higher finding of antibodies to penicillia in Group $\mathrm{I}^{\varrho}$ would show a group of individuals with a goodes capacity to produce antibodies to prevent the patho- $\overrightarrow{0}$ genic effect of moulds. In Group II, however, without this advantage, penicillia increase in the $\vec{\omega}$ respiratory tract at the expense of aspergilli (Fig. 2) and produce symptoms which compel the affected $x$ persons to give up their work. This result mighter have been anticipated by a higher sensitivity to moulds in Group II (see Table III). A different pattern of antibodies against penicillia than agains $t_{0}^{N}$ aspergilli and a different culture finding in both? tested groups suggest rather that penicillia are the $\vec{c}$ cause of symptoms in these patients in spite of longterm inhalation of spores of both species of moulds.

The relationship of moulds to the pathogenic and saprophytic flora of the bronchi is not wello known. The presence and activity of moulds may influence the growth of other agents. In our groupso the common bacteriological flora were not changed: On the other hand, there was a strikingly lowo occurrence of streptococcal infections in bo $\mathrm{yh}_{5}$ groups examined, evidently caused by the antibioficion effect of the moulds. Also a lower occurrence :0م Candida in comparison with patients suffering from other diseases of the respiratory tract was con $\overrightarrow{\overrightarrow{0}}$ firmed by extensive sensitivity of yeasts to the filtrate from $A$. niger (results to be published elsewhere).

We were not able to prove any specific fungous? disease of the lungs in the workers examined, and there was no real asthma, but the asthma-like attacks resembling the farmer's lung syndrome and caused by the direct irritation of bronchi were very? frequent.

The massive inhalation of moulds caused the transitory spastic reaction of the bronchi, but nok a permanent reduction in the functional efficiencys of the lungs in most subjects.

The inhalation of moulds caused the production. of specific antibodies, permanent positive cultura findings in the respiratory tract, and skin hypersensitivity to them.

The mycological and serological findings bear definite relation to the clinical symptoms.

The signs and symptoms are caused by penicillia rather than by aspergilli.

\section{SUMMARY}

In a group of industrial workers we studied the influence of inhaled spores of moulds from the 
species of aspergilli and penicillia on the occurrence of diseases of the respiratory tract. Even after longterm inhalation we failed to find any mycetoma of the lungs. The incidence of chronic bronchitis was increased, and in the older group all subjects suffered from chronic bronchitis. In most subjects directly after contact with the moulds, we found a condition resembling the first stage of the syndrome of farmer's lung. The positive mycological and serological examination showed that long-term inhalation of moulds causes their permanent settling down on the mucous membrane of the respiratory tract and the production of specific antibodies against them.

\section{REFERENCES}

Cavelti, P. A. (1947). J. Immunol., 57, 141.

Clayton, Y. M. (1958). Proc. roy. Soc. Med., 51, 501.

Dévé, F. (1938). Arch. méd.-chir. Appar. resp., 13, 337.

Dyson, J. E., and Evans, E. E. (1955). J. invest. Derm., $24,447$.

Epstein, S., Prince, H. E., and Morrow, M. B. (1957). J. Allergy, 28, 313.

Essellier, A. F., and Jeanneret, P. (1956). In Handbuch der Inneren Medizin, 4 th ed., ed. G. von Bergmann, W. Frey, and H. Schwiegk, band 4, teil 3, p. 616. Springer, Berlin.

Fawcitt, R. (1938). Brit. J. Radiol., n.s. 11, 378.

Frágner (1958). Parasitische Pilze beim Menschen. Prague.
Frankland, A. W., and Hamilton, E. D. (1958). Allergie u. Asthma, $4,202$.

Fuller, C. J. (1953). Thorax, 8, 59.

Hajos, M. (1956). Allergie u. Asthma, 2, 282.

Hinson, K. F. W., Moon, A. J., and Plummer, N. S. (1952). Thorax, $7,317$.

Jillson, O. F. (1957). Ann. Allergy, 15, 14.

Johnson, M. C., and Hampton, S. F. (1957). J. Allergy, 28, 170.

Kadlec, K., and Vyskočil, J. (1954). Acta med. scand., 148, 375.

Kaplan, L. (1955). Ann. Allergy, 13, 271.

Lewis, G. M., and Hopper, M. E. (1948). An Introduction to Medical Mycology, 3rd ed. Year Book Publishers, Chicago.

Mecl, A., and Vyskočil, J. In press.

Mitze, A. (1953). Hautarzt, 4, 373.

Raper, K. B., and Thom, C. (1949). A Manual of the Penicillia. Baltimore.

Riddell, R. W. (1956). Brit. med. J., 2, 783.

(1958). Proc. roy. Soc. Med., 51, 491.

Seeliger, H. P. R. (1958). Mykologische Serodiagnostik. Leipzig.

Staib, F., and Ata, S. (1958). Zbl. Bact. I. Abt. Orig., 171, 322.

Sternberger, L. A., Feinberg, A. R., Feinberg, S. M., Clarke, M., Benaim, C., and Warren, S. A. (1956). J. Allergy, 2i, 16.

Studdert, T. C. (1953). Brit. med. J., 1, 1305.

Thom, C., and Raper, K. B. (1945). A Manual of the Aspergilli. Baltimore.

Törnell, E. (1946). Acta med. scand., 125, 191.

Virchow, R. (1856). Virchows Arch. path. Anat., 9, 557.

Wagner, V. (1954). Schweiz. Z. allg. Path., 17, 94.

_ and Rejholec, V. (1952). Čsl. Biol., 1, 376.

Wegmann, T. (1956). In Handbuch der Inneren Medizin, 4th ed., ed. G. von Bergmann, W. Frey, and H. Schwiegk, band 4, teil 3, p. 680. Springer, Berlin. 